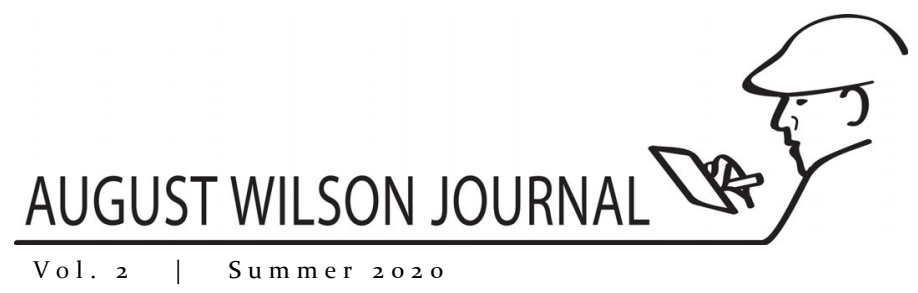

\title{
August Wilson's Legacy Felt Strongly by Those Who Perform His Works
}

\author{
Christopher B. Bell \\ Associate Professor of English, University of North Georgia \\ Editor, Legacy Section, August Wilson Journal \\ Trajan Clayton \\ Theater Studies Major at Southern Methodist University \\ Nic Starr \\ Artistic Director of Marietta's Theatre in the Square \\ Managing Director of New African Grove
}

\begin{abstract}
August Wilson has left us a portrait of life in America for most African Americans that covers a century of our history.
\end{abstract}

- Nic Starr

\begin{abstract}
Trajan Clayton and Nic Starr write about their experiences relating to the work of August Wilson. Trajan, winner of the 2019 August Wilson Monologue Competition, writes about how Wilson's plays are songs that "work together to relay the triumphs and struggles of what it means to be black." In his segment, Nic writes about how, through August Wilson, he has gratefully gained relationships with an "army of talented brothers and sisters, and many inspiring mentors."
\end{abstract}

Keywords

August Wilson, August Wilson Monologue Competition, American Century Cycle, Theatre in the Square, New African Grove

When considering August Wilson's legacy, the playwright's impact on actors cannot be overstated. No other African American dramatist has created such a wealth of dynamic characters. James Earl Jones, who won an Emmy Award for his portrayal of Troy Maxson in Fences, said, "He's so faithful to the Blackness. He's faithful like a father - that represents fidelity to him" (Bigsby 39). Testimony such as this can be found at any level of theatre where Wilson's works are performed. For this issue of the August Wilson Journal, I asked two actors to write recollections centering on their experiences with Wilson's work.

The first is Trajan Clayton, who won the 2019 August Wilson Monologue Competition, an annual contest featuring high school students from various regions throughout the country performing monologues from Wilson plays. The finals are held every year at the August Wilson Theatre on Broadway. I saw Clayton perform at the

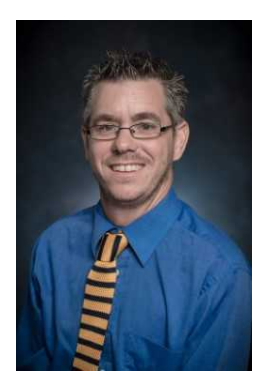

Christopher Bell, Legacy Section Editor 
regional finals in Atlanta in the Spring of 2019. All the performances were electric, but when this young Wilson Warrior delivered a speech from Caesar in Gem of the Ocean, it became immediately apparent who would carry the night.

I have also had the privilege of seeing the second actor who contributed a recollection, Nic Starr, in two performances. Nic has acted in all ten plays that comprise Wilson's American Century Cycle. The first was a production of Radio Golf at New African Grove, a community theatre in College Park, Georgia, where Starr serves as the Managing Director. Starr played Sterling. The second was a production of The Piano Lesson at the historic Morton Theatre in Athens, Georgia, which Starr directed and played Wining Boy. In both performances, I observed that Starr in particular is a gifted comedic actor in line with the tradition of Wilson's characters.

I wish to thank both Clayton and Starr for being true Wilson Warriors, contributing to the continuing legacy of August Wilson.

\section{What August Wilson Means to Me \\ Trajan Clayton}

From my very first encounter with the work of August Wilson, I was reminded of the people who came before me. People who, while living in a world of nightmares, fought endlessly to have a dream. I was reminded of people who knew what it meant to make something out of nothing. Because of the works and legacy of August Wilson, I have a divine roadmap to the center of humanity.

Being privileged enough to be born in the Information Age, understanding the impact of the Wilsonian legacy was no obstacle. When participating in the August Wilson Monologue Competition (ATL 2018), I browsed the internet for numerous hours, searching for interviews of actors and directors speaking of Wilson's work. These Wilson Warriors

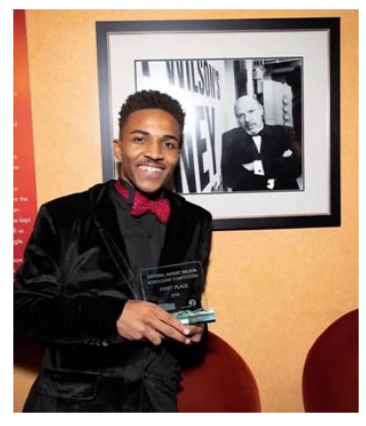

Trajan Clayton approached August's work with such dignity that it quickly became clear his work had weight to bear.

August Wilson's American Century Cycle, so precisely crafted, captured the essence of the African American experience in the $20^{\text {th }}$ Century, as well as today. Unlike any other work, Wilson's cycle authentically exhumed the sound and vernacular of our people. Being a poet lent to August a certain level of creativity that unearthed the sound of blackness, like a timeless blues tune meant for the soul. Ma Rainey said it best: "You don't sing to feel better. You sing 'cause that's a way of understanding life."

August Wilson's plays are songs. These songs work together to relay the triumphs and struggles of what it means to be black. Having this at the foundation of my theatrical upbringing truly set a standard of excellence for the kind of stories I wanted to tell. After deeply engaging with the songs of Wilson, not only did it affect my theatrical approach, I began to find great pride in my blackness. There is great responsibility to giving life to characters whose hearts pump on the page. I felt the weight that came with singing his songs.

The eminent tales personified by Wilson are the stories of love, honor, betrayal, and duty. From these epic tales one might find great wisdom. Such wisdom one might gain from sitting at grandma's kitchen table. Wisdom that was passed down from generations. His work exhumes the black experience, giving life to voices willing and worthy to be heard. By giving us these characters, he gave us a lifetime worth of experiences and made that experience accessible to all.

Wilson's literary cannon and its authenticity gives its readers ownership of its characters. So vibrant and unapologetic, the characters created by August Wilson are family. These characters, like auntie and uncle, can teach a thing or two about survival. But long after auntie and uncle and mama and daddy are gone, we can look to this work that August 
left here for us and find those familiar voices. For this work can be a mirror, you shall look inside and find yourself.

If it were not for the works and legacy of August Wilson, I would not be where I am today. From my participation in the August Wilson Monologue Competition, both regionally and nationally, I have gained lifelong connections and experiences that continue to build upon the foundation of my artistry. I can honestly say I had given up on the thought of higher education, but because of my pride and dedication to the work of August Wilson, doors began to open. I was introduced to a professor from Southern Methodist University in Dallas, Texas, and from that moment on I knew his work had the potential to change lives. I am a living witness.

Competing in the August Wilson Monologue Competition was the one of the most immersive experiences of my life, as short as it has been. I found great power in the unity of young people. To have young people, from all different cultural backgrounds speaking these words, it was easy to see that, as specific as it is, Wilson's work exceeds all barriers. He wrote this to let us know that we are all worthy. After winning the competition, I had the privilege of speaking with Wilson veterans such as Anthony Chisholm, who has performed in several Wilson plays on Broadway. To know the extent of his association with the Wilson legacy, and to hear how highly he spoke of August's work, I knew that, like Mr. Chisholm, it was up to me to do whatever I can to keep this legacy alive. Not only is this work the foundation of my theatrical upbringing, it is my validation. Because of this work, I know that I am enough, and that there is enough of everything for me.

Performing the work of the master craftsmen brings up memories of those we've lost, and that is the beauty of it. Through the work of Wilson, we honor them. When I think of the plays August wrote, in context to the experiences of those who paved the way for me to be free, I feel nothing but admiration and gratitude, for they lived their worst nightmares so that we wouldn't have to. The powerful sounds unearthed by August Wilson are the voices of these people. They are the voices of my people. Being the next generation of Wilsonian Warriors, I feel strongly obligated to keep their voices alive.

Just as much as the characters of Wilson's work are family, the same can be said about the ensembles created when presenting his work. The time spent competing in the August Wilson Monologue Competition was spent with talented and reverent company. People whom I call family. Understand this is not a term that I use lightly. Through my experience with the work of August Wilson, I have gained a second mother, an army full of talented brothers and sisters, and many inspiring mentors, all because of our shared love of Mr. Wilson.

August Wilson, to me, is the voice of the African American experience. His dramatic "songs" help to fill the emptiness of this world. By giving authentic commentary to black lives and livelihood, his work showed us that we are all worthy of being heard. From the multiple interviews I watched and my dedication to keeping his voice alive, it is foolish to say I know him, but August Wilson is a part of who I am. For his legacy, I am grateful. Thank you, August, for giving us voice. Thank you for showing us the importance of finishing what we start. Thank you for showing us the difference between the "crookeds and the straights." Because of August Wilson I will never forget where I come from. Thank you God, for giving him to us.

\section{What August Wilson Means to Me}

Nic Starr

When asked, "What does August Wilson mean to you?" my answer could be summed up in a single word, in bold letters, underlined with an exclamation point with a Wilsonian slant: EVERYFUCKINTHANG!

To understand what could elicit such emotions from a sixty-year-old man who has long outlived a belief in heroes since his mother passed, you have only to take the 
time and read any play from August Wilson's American Century Cycle.

My introduction to Mr. Wilson's work did not happen until I was thirty. I was a student at Paine College, taking classes through the military. Professor Evelyn Etheridge put the play Fences in my hands and told me to read it. She later asked me to be a part of her drama troupe, and I was happy to join. We performed numerous other productions, but she would always come back and talk to me about Fences.

At this point, I knew nothing about August Wilson, but his words spoke to me as if he knew me on a first name basis. I was Cory! I grew up knowing Troy; he was my Father. I had an Uncle Gabe ... and my hero even at that time, my mother, was embodied in Rose! I KNEW THESE PEOPLE!?!

I became frustrated because I couldn't understand why we were doing all these other plays instead of Fences, and Ms. Etheridge looked me in my eyes and said, "Because you aren't ready." I never forgot that, and when we finally mounted Fences, that production forever changed my life. That singular moment gave my life purpose. Now, thirty years later, I've performed in all ten plays of the American Century Cycle and have directed four.

Even so, I take more pride in being able to share his work with others. To live a life with purpose is an amazing feeling. No matter the size, big or small, your purpose is everything. I remember feeling like I had been cheated be-

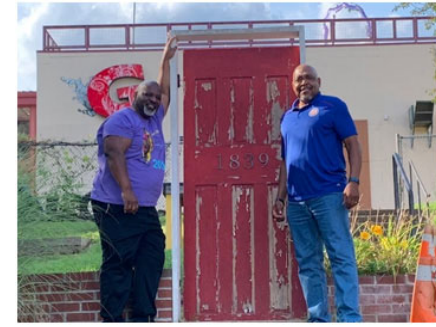

Nic Starr (right) posing with friend Keith Franklin at the Red Door at 1839 Wylie Ave in Pittsburgh's Hill District cause I was not introduced to August Wilson earlier. It became my purpose, no matter what else I did in life, to make sure that others knew his work, and what it meant to our community as artists and as people. I felt like I had found a gold mine and I wanted to share it.

I graduated from Paine and retired from the military. I moved to Atlanta and became a part of its theatre community. In the interim I found work as a mental health associate on an adolescent unit. You want to calm down a group of restless kids? Talk story. Learn to tell stories, and what better stories to tell than those from the American Century Cycle? It was our Friday night thing: Read the children a scene from the Cycle and talk about it. It always ended with them trying to play out the scene. These characters come to life easily because you already know them. They are part of your family, live in your neighborhood. It felt good to share these characters with my patients and watch them learn more about themselves and those around them. I took this theory with me when I became an educator. I taught middle and high school theatre for fifteen years. In every school that I ever taught, August Wilson was part of the curriculum. I personally purchased each play of the American Century Cycle and fought for them to be placed in the school's libraries in which I taught. Why? Because it is so very important for students to be able to pick up a book in their own school that they can identify with, relate too, and be motivated by. This is EVERYFUCKINGTHANG!

Now that I have left the classroom, I have more time to share what I have learned in other ways: artistic director, producer, director, actor, acting coach. There is an old African proverb that states, "If you think you are poor, you are poor!" Many times, unless you are told something different or you see something different, you just don't know. You become stuck in your own struggle. August Wilson has left us a portrait of life in America for most African Americans that covers a century of our history. We are now able to step into any decade from that century and witness the struggles and triumphs of African Americans. You can walk right alongside these characters and live in those moments because the writing is so vivid and speaks in your language, unashamed, unapologetic. August Wilson gave our lives breath! We lived these struggles, fought these fights, lost, and sometimes won these battles. His words spoke truth poetic, and they 
still speak that same truth today.

This is thirty years after my introduction to Fences. I am still thankful to Ms. Evelyn Etheridge for helping me "find my song." I feel truly blessed to have lived in the lifetime of a true griot, a true storyteller, who was not afraid to tell our stories and tell them in a way that not just African Americans understood, but the world understood. I feel he had a great part in humanizing a race of people some didn't see as human. Not only did he give us insight into ourselves, but he gave others the opportunity, if they choose to take it, to gain some understanding and respect for the African American experience here in America. I feel that it celebrated and gave reason for others to celebrate African American culture. To this day his words still ring true: "[I]t was a long time before I could cut it down to where I could handle it." Troy Maxson speaking about life, the world.

So what does August Wilson mean to me? He was the one who helped me cut it down to size, understand it, respect, appreciate, and celebrate it. Thank you Mr. Frederick August Kittel...thank you, August Wilson!

\section{Work Cited}

Bigsby, Christopher. "Been Here and Gone." The Cambridge Companion to August Wilson. Edited by Christopher Bigsby, Cambridge UP, 2007, pp. $202-213$.

\section{Author Bios}

Christopher Bell is Associate Professor of English at the University of North Georgia and Editor of the Legacy Section of the August Wilson Journal.

Trajan Clayton was awarded first place at the $11^{\text {th }}$ Annual August Wilson Monologue Competition National Finals in New York City, where he performed a monologue by Caesar from Gem of the Ocean. He is currently a student at Southern Methodist University in Dallas, Texas, majoring in Theatre Studies. \#BlackLivesMatter

Nic Starr is the Artistic Director of Marietta's Theatre in the Square and the Managing Director of New African Grove, two companies in the Atlanta, Georgia, area that specialize in productions of African American plays. Starr has acted in each play of the American Century Cycle and is well on his way to completing a second run through the plays. A former educator and retired Army veteran, Starr continues to work with youth in the Atlanta area, bringing August Wilson's work to a new generation of Wilson Warriors.

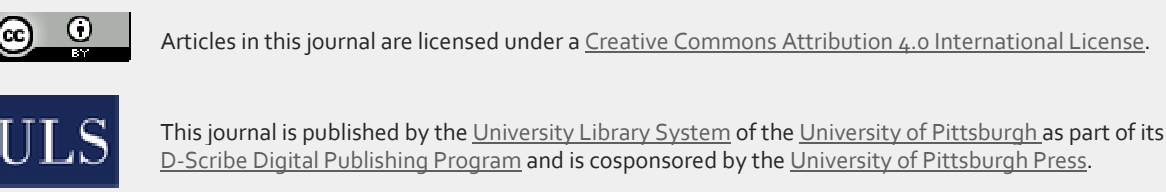

